\title{
The improvement of sewerage fee imposition system for efficient rainwater management
}

\author{
효율적 빗물관리를 위한 하수도 요금체계 개편 방안
}

\author{
Park, Kyoo-Hong ${ }^{*} \cdot$ Kang, Byong-Jun ${ }^{1} \cdot$ Park, Joo-Yang ${ }^{2} \cdot$ Park, Wan-Kyu ${ }^{3} \cdot$ Kim, Sung-Tae ${ }^{4}$ \\ 박규홍 ${ }^{*}$. 강병준 ${ }^{1} \cdot$ 박주양 $^{2} \cdot$ 박완규 $^{3} \cdot$ 김성태 $^{4}$
}

'School of Civil and Environmental Egineering, Chung-Ang University · '2Department of Civil and Environmental Engineering, Hanyang University ${ }^{3}$ School of Economics, Chung-Ang University · ${ }^{4}$ School of Economics, Cheongju University

1중앙대학교 사회기반시스템공학부 · 2 한양대학교 건설환경공학과 - ${ }^{3 ㅈ ㅜ ㅇ ㅇ ㅏ ㅇ ㄷ ㅐ ㅎ ㅏ ㄱ ㄱ ㅛ ~ ㄱ ㅕ ㅇ ㅈ ㅔ ㅎ ㅏ ㄱ ㄱ ㅘ ~-~}{ }^{4}$ 청주대학교 경제학과

\begin{abstract}
As sewer flooding frequents due to localized and concentrated stormwater and increased non-permeable surface area after urbanization, building cities with sound water recycle and accordingly efficient management of rainwater is demanded. To do this, the existing sewage (including rainwater) fee imposition system should be philosophically evaluated. This study presents problematic issues of the existing domestic sewage fee imposition system considering the principle of sharing costs on the service of sewage and rainwater collection and treatment. Four methods to improve the existing sewage fee imposition system are suggested: 1) imposing stormwater fee according to Polluter Pays Principle, 2) clarification of the share of public sector, 3) reducing or exempting the sewerage fee for inhabitants reducing urban runoff by constructing their own rainwater management facilities, 4) imposing charge for discharging rainwater to sewers due to new development action. Short, mid, or long term planning for rainwater management is recommended considering the situation of each municipality.
\end{abstract}

\section{Key words : Rainwater management, Sewerage fee, Sewerage fee imposition system, Polluter pays principle} 주제어 : 빗물관리, 하수도 요금, 하수도요금 부과체계, 오염염자 부담 원칙

\section{1.서 론}

최근 기후변화로 인한 강우특성의 변화로 최근 도심지역의 침수가 빈발하고 있어, 이를 배제하기 위한 하수관로의 통수용량을 증대하는 하수관로 정비사업 및 하수저류시설 건설 등의 침수방지 대 책이 시급하다. 또한 환경부에서는 공공하수처리 시설의 우천시 미처리 방류 하수에 대한 규제 강 화를 위한 간이공공하수처리, CSOs 대책 등에 대 한 요구가 커져, 우천시 물재생센터의 방류수 수 질 뿐 아니라 방류수역 수질관리가 더욱 어려워지

- Received 04 July 2014, revised 13 October 2014, accepted 15 October 2014.

${ }^{*}$ Corresponding author: Tel : +82-2-820-5886 Fax : +82-2-812-4284 E-mail : kpark@cau.ackr
고 더 많은 재원 투자가 필요하지만, 중앙정부와 지자체의 하수도담당부서는 하수도 외의 다른 분 야와 경쟁하여 예산 확보를 하는 데에 많은 어려 움이 있는 듯하다.

최근 빗물배제와 빗물처리에 관한 요금제 도입 에 관한 논의가 진행되어 왔다. 특히, 2012년 9 월에 개최된 '서울시 빗물세 도입을 위한 정책토 론회'(Seoul Metropolitan Government, 2012) 에서, 빗물관리를 위한 재원 마련을 위해 하수도 요금체계 개선을 통해 빗물과 오수를 분리하여 하 수도요금을 부과하는 방식에 대한 토론이 있었으 나, 증세에 대한 저항, 불투수면 조성책임을 시민 에게 전가한다는 등의 반대의견이 크게 표출된 바 
있다. Ministry of Environment (2012)에서는 '비점오염원관리를 위한 빗물오염제 도입방안' 연구를 진행한 바 있으나, 현행 하수도요금이 수 도요금에 합산 고지되고 있는 것이 일반적인데 비점오염원관리를 위한 빗물요금이 점오염원인 하수에 대한 사용료에 포함되어 징수될 경우, 기 존의 하수도요금과는 별도의 세입 - 세출체계가 만들어져야 해서 많은 혼선을 야기할 수 있음 이 충분히 고려되지 않은 것으로 판단된다. 또한 토지피복 및 빗물유출을 고려한 하수도요금 부 과방식 개선방안을 위한 연구가 수행되고 있다 (Kim et al., 2014). 한편, 인천시는 2013년 하 수도법 제 61 조 제 3 항의 원인자부담금의 산정기 준과 징수방법을 지자체의 조례로 정할 수 있다 는 규정에 입각하여 하수관로 신설 및 증설시 우 수량을 기준으로 공공하수관로 신설 - 증설 등을 위한 비용을 부과하도록 인천시 하수도사용조례 일부 개정 조례안(Incheon Metropolitan City, 2013)을 통과시켰고, 이 때 빗물유출량에 관경 별 표준단위공사비를 적용하여 비용을 산정하도 록 해, 우리나라 최초로 빗물부담금제를 도입한 지자체가 되었다.

일본은 1961년에 제1차 하수도재정연구위원 회를 개최하여 우수 공비의 원칙 및 오수 사비 의 원칙 등을 논의하였고 자본비용에 대해 우수: 오수의 부담비율이 5:5라는 결론을 내린 바 있 다. 1966년, 1973년, 1979년, 1985년에 와 제 2-5차 하수도재정연구위원회에서 이에 관한 지 속적인 논의가 있었고, 자본비용에 대해 우수:오 수의 부담 부분이 $7: 3$ 이며, 유지관리비에 대해 오수:오수의 부담비율은 $3: 7$ 이라는 결론을 내린 바 있다. 한편, 일본 하수도사업의 주요 Ministry of Internal Affairs and Communications(2006) Ministr y of Internal Affairs and Communications(2013) Tokyo Metropolitan Government(2013) 자본비의 경우 빗 물과 오수에 대한 공비:사비의 비율을 $61: 39$, 유 지관리비의 경우 빗물과 오수에 대한 공비:사비 의 비율을 $24: 76$ 으로 정하고 있다.
독일에서는 상수도 사용량에 따른 하수요금 부과에 대한 형평성 문제가 제기되어, 1985년 독 일 연방행정법원 및 지방 고등법원에서 원인자 부담원칙에 입각한 요금 부과의 법적 형평성 제 고를 위해 하수도요금을 빗물배제를 위한 사용료 와 오수배제를 위한 사용료로 분리 징수해야 한 다는 독일 법원의 판결이 있었다. 이 판결은 독 일에서 빗물에 대한 하수도요금제도를 실시하는 발상의 전환을 가져오는 결정적인 모티브가 되었 다(Henning, 2000 ; Kwon and Hur, 2010). 현재 독일에서는 두 개의 하수도 요금 산정방식 을 사용하고 있으며, 상수 사용량을 기준으로 한 하수도요금이 함께 산정되는 통합산정법과 상수 사용량에 따라 발생하는 오수 요금과 대지 경계 선 내에 불투수면에서 발생하는 우수에 대한 요 금을 이원화하여 징수하는 분리산정법이 있다. 2010년 현재 인구 10 만명 이상 도시의 약 $73 \%$ 는 분리산정법이 적용중이며, 지자체의 하수도 사 업 주체의 규모가 작을 경우 시행비용이나 행정 효율 측면에서 통합산정법을 택하는 경우가 많다 (DWA, 2007; Kwon and Hur, 2010).

미국은 1980년대 이후 통합적 물관리 체계에 관심을 갖고 1) 수자원의 개발과 공급, 2) 하수의 차집 및 처리, 3) 강우유출수의 양과 질의 관리 에 초점을 두었으며, 자원으로서의 빗물의 다양 한 기능에 주목하게 되어 하천수 및 지하수의 함 양, 습지 조성 및 보호, 여가, 생태 등을 중시하 는 분위기가 마련되었다. 빗물관리 개념 변화에 따라 분류식하수관로시스템(MS4s; Municipal Separate Sanitary Sewer Systems)의 건설 및 유지관리비용의 급증 및 Stormwater Phase I \& II Program, 도시침수 및 수질규제 등 강우 유출수에 대한 규제가 강화됨에 따라 신규재원 마련의 필요성이 증대하였다. Western Kentucky University 조사(Campbell, 2012)에 의 하면, 2007년 미국의 635개 지자체에서 빗물요 금제가 시행되는 것으로 조사되었으나, 2012년 현재 미국의 약 1314 개 지자체에서 빗물요금제 가 시행되고 있어(Campbell, 2007 2012), 
약 5 년 사이에 거의 2 배 이상으로 급증하였다.

우리나라의 하수도요금제는 일본과 같은 하수 도요금제와 매우 유사하게 운용되고 있으나 우 수공비/오수사비 등과 같은 하수도재정부담의 원칙에 대한 논의나 연구가 없이 과거의 체계 를 답습하고 있는 상황이다. 이런 하수도요금체 계는 오수량에 기초하여 빗물요금까지 포함하여 징수되기 때문에 이 요금제가 지속되다 보면, 빗 물요금에 대해 독일과 같이 형평성에 관한 법적 문제가 제기될 우려가 있다. 미국은 우리나라와 규모면에서 큰 차이가 있고, 고도의 지방자치제 도가 시행될 수밖에 없어, 우리나라의 제도 시 행에 벤치마킹하기에는 많은 검토가 필요하다.

본 연구에서는 빗물을 고려할 경우의 하수도 서비스의 비용부담원칙을 검토하고, 이에 따른 현행의 국내 하수도요금체계의 현황과 문제점 및 하수도요금체계의 개편과 관련된 법제도를 검토하여, 빗물배제 및 관리를 위한 하수도요금 체계의 개선방안을 4 가지로 구분하여 제안하고 자 한다. 하수도요금체계는 지자체별로 하수도 사용조례를 통해 운용하므로 국내 모든 지자체 의 경우를 모두 고려하기 어려워, 본 연구의 공 간적 범위를 서울시로 제한하여 하수도요금체계 개선방안을 검토하고자 하였다. 4 가지의 개선방 안은 원인자부담원칙에 의한 빗물요금제 도입방 안, 공공비용의 분담방안, 빗물관리시설 설치자 에 대한 하수도요금 감면방안, 빗물유출부담금 제의 도입방안이다. 4 가지의 하수도요금체계 개 편 방안에 대해 각각 그 목적, 특징, 문제점 및 고려사항 등에 대해 정리하여 제시하였다. 특히, 공공비용의 분담방안에 대한 제안에서는 우리나 라의 빗물과 오수에 대한 공공 및 개인의 부담비 율, 하수도사업에 대한 국고보조금의 비율 등에 대해 전문가를 대상으로 한 설문조사를 수행하 여 그 결과를 제시하였다.

\section{2. 빗물을 고려한 하수도서비스의 비용부담 원칙}

\section{1 국내의 하수도요금체계}

하수도법에서의 하수도사용료는 공공하수도 를 사용하는 자로부터 하수도사용료를 징수할 수 있도록 규정되어 있고 “하수”의 범위에 빗물 을 포함하고 있어 빗물에 대한 하수도사용료를 부과할 수 있는 근거는 있으나 명확하지는 않은 것으로 판단된다. 하수도사용료는 공공하수도의 유지관리비, 감가상각비 등 사업의 계속성 유지 를 위해 필요한 비용을 합산한 금액의 범위내에 서 정하도록 규정되어 있어 유지관리비 성격을 가지고 있다.

국내 대부분 지자체의 하수도요금 산정방식은 하수도법 시행령 제 36 조에 따라 사용자가 공공 하수도에 내보내는 하수의 양과 하수의 질 및 사 용형태를 고려하고 있다. 일반적으로, 하수의 양 은 상수 사용량을 기준으로 하며, 사용형태는 공 공용, 가정용, 일반용, 욕탕용 등으로 구분하고 있다. 하수배출량은 각 지자체 하수도 사용 조례 에 따라 하수배출량의 인정 기준을 설정한다. 예 를 들어, 서울시의 하수도 사용료조례 제 24 조에 는 공공하수도 사용자와 상수도 사용자가 같은 경우는 상수도 사용량 기준으로 하되, 공공하수 도 사용자가 상수도 사용자가 아닌 경우에는 신 고량 또는 검침량으로 하며, 물의 사용량과 하 수의 배출량이 현저히 다른 경우에는 신고량으 로 하고, 공공하수도 사용자가 수도 사용자이면 서 지하수 등을 겸용으로 사용하는 경우엔 수도 급수량과 지하수 등의 사용량을 합산한 양으로 한다. 요금 산정은 각 지자체 하수도 사용조례에 따라 배수구역 또는 하수처리구역 내의 사용자 는 배출하는 하수의 양과 업종에 따른 요율표에 의해 산정하게 된다. 지하수는 사용하지 않고 공 공하수도로 배출하는 $60 \mathrm{~m}^{3}$ 월 미만은 미부과하 지만, 사용여부 및 업종구분 없이 $60 \mathrm{~m}^{3}$ 월 이상 의 지하수는 유출지하수 단가를 적용한다. 하수 도 사용료는 공공하수도에 배출하는 하수의 사용 량에 따라 요금을 부과하는 체계로 구성되어 있 다 (Seoul Metropolitan Government, 2014). 
국내 하수도요금체계는 표면적으로는 빗물이 포함되어 있지 않은 것으로 보이지만, 내면적으 로는 빗물을 포함하는 것으로 해석할 수 있다. 왜냐하면, 부과된 요금으로 빗물배제와 처리의 기능이 포함된 하수관 신 · 증설과 유지보수 및 하수처리장의 신 · 증설, 운전 등의 비용에 지출 하여 사용하고 있기 때문이다. 상수사용량 및 상 수의 사용형태와 연계하여 오수배출량으로 부과 함으로써 빗물에 대해서는 요금부과가 이루어지 지 않고 있지만, 지출의 용도로 볼 때는 빗물의 배제와 처리에 '빗물을 포함되지 않은 채 징수한 하수도요금'을 사용하고 있는 것이다. 결국 상수 사용량에 대한 단가가 부풀려져 책정되어 빗물 배제 및 처리에 필요한 비용까지 포함하고 있는 것으로 볼 수 있다는 것이다.

이런 상황은 하수도사용자에게 불공정 · 불합 리한 상황을 만들어낼 수 있다. 다음과 같은 예 를 들어 설명해보자. 주차장이 구비되지 않은 목 욕탕의 경우 빗물로 인한 공공하수도의 사용을 거의 하지 않지만 상수사용량이 많아 하수도요 금을 많이 내게 되지만, 불투수면의 주차장이 있 는 대형마트의 경우 상수사용량이 상대적으로 적은 반면 공공하수도로 빗물배제량이 많아 하 수도사용을 많이 함에도 불구하고 적은 하수도 요금을 내도록 되어 있다. 결국 과거의 독일과 같이 우리 하수도요금체계는 수도(지하수 포함) 사용자가 빗물처리비용까지 함께 지불하는 불합 리한 형태로 구성되어 있으며, 불합리성을 개선 하기 위해서는 하수도요금체계에서 빗물배제 및 처리에 관한 비용을 분리 산정할 수 있는 합리적 하수도요금 체계가 필요하다고 하겠다.

\section{2 하수도서비스의 공공재 및 민간재 성격}

하수도사업에 필요한 비용은 하수도 건설비용 과 유지관리비용으로 구성되는데, 이 비용의 공 공과 민간의 분담 문제가 하수도 재정의 가장 기
초가 된다. 공공재는 비배제성*과 비경합성 ${ }^{\dagger}$ 의 2 가지 기준을 만족시키는 재화를 일컫는다. 하 수도는 도심침수의 방지, 공공수역의 수질보전, 공중위생의 향상, 생활환경의 개선, 도시물순환, 쾌적한 수변공간 창출 등 공공재로의 역할이 크 다. 한편, 수세식 화장실 사용에 의한 주택환경, 생활환경의 개선 및 하수처리구역 내로 편입된 주택의 집값 상승 등의 효과는 해당주택 또는 그 생활환경의 이용자에게 귀속되므로 민간재의 성 격을 갖는다. 이처럼 하수도사업은 공공재로 생 각되지만, 사적 편익도 수반하는 점에서 민간재 적 측면이 있다. 상수도서비스는 사용자의 요구 에 대응해 공급하므로 수도사업의 근간이 되만, 하수도서비스는 단순히 개인의 요구만으로 하수 도사업이 이루어질 수 없는 공공적 측면이 있다. 즉, 하수도는 개인의 편익을 위해 배수구역내 특 정 주민에게만 침수예방 서비스를 제공할 수 없 는 차이가 있다.

\section{3 빗물과 오수의 배제 및 처리 비용과 공공 . 민간의 부담}

앞서 언급된 바와 같이, 일본은 오수 사비, 우 수 공비 원칙에 의해 빗물은 공공에서 부담하고, 오수는 민간이 부담하는 원칙이 일반적으로 적 용되고 있다. 오수에 관한 하수도 역할의 공공성 (신속한 오수배제로 도시환경 개선)을 인정하여 공공 부담의 필요성이 있는 한편, 빗물에 관한 하수도 역할의 민간 부담 부분(개인소유지에 내 린 빗물배제를 위한 공공하수관로 사용)이 있음 에도 불구하고, 양자를 상쇄하여 결국엔 빗물에 관한 비용은 공공부담, 오수에 관한 비용을 민간 부담이라고 하는 입장이 있다(일본에서 이를 '상 쇄론'이라 일컬음).

우리나라는 빗물에 관한 비용은 공공부담, 오 수에 관한 비용을 민간 부담이라고 하는 이런 상 쇄론을 어느 정도 수용하고 있는 듯하지만, 실제

* 재화가 공급하는 서비스 편익이 특정의 주체를 넘어서 광범위하게 미치는 성질을 가질 때, 즉 서비스 편익을 특정 주체에게 한정하는 것이 곤란할 때, 그 재화 서비스는 비배제성을 갖는다고 일컬음

서비스 편익이 불특정 다수의 사람들에게 대해서 양적으로 저하하지 않는 성질을 가질 때 그 재화서비스는 비경합성이라 일컬음. 


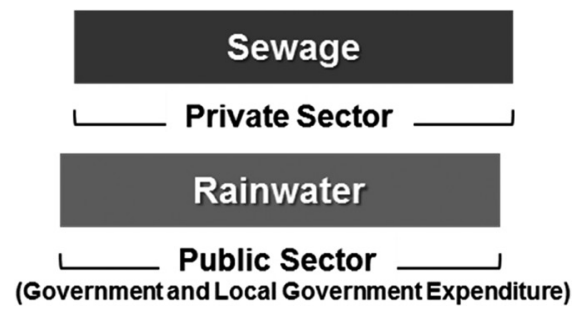

Fig. 1. Concept of sharing costs of rainwater and sewage collection and treatment in public and private sectors.

로는 이에 대한 분명한 비용분담비율이 정해져 있지도 않고 공식적으로 논의된 바가 없었다. 일 본에서 제기된 상쇄론이 성립하기 위해서는 빗 물에 관한 민간부담부분과 오수에 관한 공공부 담부분이 양적으로 같거나 비슷해야 하는데, 이 비율을 지속적으로 점검할 필요성이 제기된다. 점점 더 엄격해지는 수질환경기준의 달성을 위 해서 오수 분야에 투자량이 꾸준히 증가해 왔지 만, 최근의 초기우수의 방류오염부하 저감을 위 한 규제, 간이공공하수처리시설에 관한 규제 등 빗물의 처리에 관한 규제가 신설되고 있는 상황 에서는 우수 분야에 대한 투자량이 증가할 필요 가 있을 것이다.

이러한 변화를 무시하고 상쇄를 전제로 하는 지나치게 단순한 과거의 일본방식인 오수의 민 간부담, 우수의 공공부담의 원칙'보다는, 오히려 독일의 하수도요금에 대한 오수와 빗물의 분리 산정방식을 검토하여 더 합리적인 비용부담 원 칙에 대해 살펴보고, 우리의 하수도요금체계 개 선방안으로 활용할 필요가 있을 것이다.

\section{4 국가와 지방자치단체의 역할과 부담}

하수도에 관한 비용의 공공 또는 민간 부담이 명확해진 후에는 국가와 지자체의 역할과 비용 부담의 방법이 문제가 될 수 있다. 하수도사업 은 지역주민의 건강유지, 공중위생의 향상, 생 활환경 개선 등에 관련되므로 지자체가 행하는 것이 적절하다고 여겨지지만, 대규모의 행정구 역을 초월하는 공공수역의 수질 보전 등의 공공
적 역할에 대해 국가적 규모로 행하는 하수도사 업이 있다면 국가가 해야 할 사업이 될 것이다. 따라서, 하수도 정비는 지자체가 책임을 지고 행 하며, 국가는 국가적 견지에서 하수도를 통한 국 민보건향상 및 생활환경의 개선, 공공수역의 수 질 보전 등의 공공 역할에 대해 지자체가 부담 해야 할 공공의 부담의 일부를 보조하고 그 하 수도 정비를 적극적으로 추진해야 할 입장에 있 는 것이다.

하수도법 시행령 제 36 조 2항에는 "공공하수 도관리청은 법 제 65 조제 1 항에 따라 사용료를 정 하는 경우 공공하수도의 사용에 대하여 공공하 수도의 유지관리비, 감가상각비와 시설을 위한 차입금의 이자 및 그 밖에 사업의 계속성을 유 지하기 위하여 필요한 비용을 합산한 금액의 범 위에서 사용자가 공공하수도에 내보내는 하수의 양, 하수의 질 및 사용 형태를 고려하여 사용료 를 정하여야 한다" 라고 하여, 하수도의 유지관 리비를 하수도요금으로 충당하도록 명시하고 있 다. 또한 지방공기업법 시행령 제 5 조에는 일반 회계 등이 부담할 경비로 각 사업에 공통적으로 적용되는 경비는 1) 공공의 목적을 위한 무상공 급에 소요되는 경비, 2) 공공의 필요에 의하여 요금 등의 공급가격이 발생원가 이하로 책정되 거나 발생원가 이하로 유지됨에 따른 발생원가 와 공급가격과의 차액, 3) 지역개발 등에 따른 선행투자에 소요되는 기본경비, 선행투자에 의 한 시설의 유지비, 선행투자에 소요되는 외부차 입금에 대한 원리금 상환액이며, 하수도사업에 한하여 적용되는 경비로는 빗물처리시설의 설치 및 유지에 소요되는 경비를 명시하고 있다.

이에 빗물을 포함한 하수도요금에 대한 비용 부담원칙, 원인자 부담원칙에 대해 비용분담의 근거, 주체, 비율 및 공공부담비율의 조정 방안 등에 대해 검토하여 개선방안을 제시하고자 한 다. 또한 빗물관리시설에 대한 인센티브로 하수 도요금 감면 가능성, 원인자부담금의 부과대상 확대방안에 대해 검토하였다. 


\section{3. 연구 결과 및 고찰}

\section{1 원인자 부담 원칙에 의해 빗물요금제 도입 방안}

원인자부담 원칙에 따라 오수비용은 상수도 사용량, 우수비용은 불투수면을 기준으로 산정 하여 부과기준에 대한 적법성 시비 해소와 하수 도사업 공공부담 확대 및 빗물의 공공하수관로 유입저감을 통한 건강한 물순환도시 조성을 위 한 방안이다.

이 제도의 주요 특징은 빗물유출량에 따른 요 금부과로 부과기준에 대한 적법성 시비를 해소 하고 총 세출액 기준에 의한 요금 산정으로 소 요재원 $100 \%$ 징수가 가능하며, 하수도사업비에 대한 국고보조금 및 시비 지원을 가능도록 하는 것이다.

\begin{tabular}{|c|c|c|c|}
\hline Sewage & \multirow{2}{*}{$\begin{array}{c}\text { Central } \\
\text { Government } \\
\text { Rainwater }\end{array}$} & $\begin{array}{c}\text { Local Government } \\
\text { Expenditure } \\
\text { Subsidy } \\
\text { (Road, Square, } \\
\text { Park etc.) }\end{array}$ & $\begin{array}{c}\text { Rainwater } \\
\text { fee }\end{array}$ \\
\hline
\end{tabular}

Fig. 2. Financial sources of sewerage service based on Polluter Pays. Principle.

제도 도입을 위한 선행조건의 첫 번째는 법적 인 근거 마련이다. 현행 하수도법으로 빗물요금 의 징수가 가능하지만 여러 가지 문제점을 해결 해야 하고 논란이 될 수 있어 법에 명확한 징수 근거의 명문화가 필요하다. 두 번째는 시민 동 의 및 수용이 필요하다. 지난 2012년의 '빗물세 도입을 위한 정책토론회’에서 불투수면적이 늘 어나도록 도심개발을 추진한 책임의 전가, 행정 편의주의적인 발상의 새로운 세금부과, 빗물요 금 도입에 따른 서민부담 증가 등의 반대의견이 제시되었다. 독일사례의 경우도 도입 초기에 불 투수면적이 넓어 많은 빗물요금을 납부하게 될 대형창고업자 등을 중심으로 한 거센 반발이 있 었다. 이 때문에 베를린시는 빗물요금제 할당을 위한 정밀 측정과 시민 설득작업 등에 4 년간의
노력을 기울였다. 세 번째는 관련인프라 구축이 다. 빗물 요금제 산정을 위한 활용데이터와 관 련인프라가 완전하게 구축될 필요가 있으며, 다 양한 조건에 의한 데이터 획득 및 활용 방안, 산 출 방법이 필요하다. 마지막으로 오수와 우수의 비율 및 공공부분의 비용 분담 비율이 규정되어 있지 않으므로 이에 대한 사회적 공감대 형성과 함께 공공부분에 대한 국고 등의 지원기준 설정 이 필요하다.

이와 같이 엄격한 의미의 원인자 부담 원칙을 적용하기 위해서는 시민의 동의, 법적근거, 관련 인프라, 오수와 우수의 비율 및 공공부분의 비용 분담 등 선행 해결과제가 많고 복잡하므로 장기 적인 추진 계획이 필요하다. 따라서 시민의 여론 수렴, 정부 · 국회 · 민간단체 · 전문가 등과 공조 체제를 유지하여 빗물요금제 도입을 위한 공감 대를 형성한 후 법적인 근거와 관련인프라 구축 과 같은 단계별 추진이 타당할 것으로 판단된다.

\section{2 공공의 비용부담 확대방안}

하수도사업은 도심침수 방지, 공공수역의 수 질보전, 공중위생의 향상 등 공공재로서의 역할 도 수행하고 있으므로 공공의 비용부담 확대가 필요하다. Table 1과 같이 일본(동경)과 국내(서 울) 하수도사업의 공공부담 비율을 비교하면 서 울은 동경도의 $6.7 \%$ 수준에 불과하다. 서울특별 시의 경우 상수사용량에 빗물배제 및 처리비용 을 포함하여 부과하는 개념이라 일반회계 지원 이 미미하게 된 애매성이 있긴 하지만, 국고보조 의 지원도 매우 불규칙적이고 미미한 수준이므

Table 1. Comparison of cost sharing for sewerage business between Japan and Korea (average values in 2011 2013)

\begin{tabular}{|c|c|c|c|}
\hline - & Tokyo & Seoul & Remark \\
\hline Total & 42.0 & 2.8 & \multirow{3}{*}{$\begin{array}{l}\text { The government } \\
\text { subsidies in Seoul is } \\
\text { only } 6.7 \% \text { of those in } \\
\text { Tokyo. }\end{array}$} \\
\hline $\begin{array}{l}\text { Central Govern- } \\
\text { ment Subsidy }\end{array}$ & 9.2 & 0.5 & \\
\hline $\begin{array}{c}\text { Local Government } \\
\text { Subsidies }\end{array}$ & 32.8 & 2.3 & \\
\hline
\end{tabular}


로, 공공의 비용부담이 절실하다고 할 수 있다. 특히 최근의 강남역과 광화문 등 우리나라의 수 도인 서울의 중심에서 도심침수가 일어나고 있 는 상황에서 국가차원의 적극적인 지원의 당위 성은 꽤 큰 것으로 판단된다.

한편, 일본 동경도의 경우 유지관리비에 대한 오수 대 빗물의 비율은 76:24이며, 건설비에 대 한 오수 대 빗물의 비율은 39:61로 구분하고 있 다. 독일 베를린의 경우, 하수도 세입 중 오수와 빗물의 기본분담비율을 약 60:40으로 구분하고 있다. 이에 앞서, Pechner (1997)는 합류식하수 관로의 건설비 중 오수 대 빗물의 비율을 $46: 54$ 로, 하수처리시설의 유지관리비 중 오수 대 빗물 의 비율을 87.5:12.5로 제시한 바 있다. Seoul
Unstitute(2002)의 연구에 의하면, 서울시의 하수도 건설비 중 오수 대 빗물의 비율을 $21: 79$ 로, 하수처리시설의 유지관리비 중 오수 대 빗물 의 비율을 68:32로 제시하였다. 본 연구를 통해 전문가를 상대로 설문조사한 결과, 우리나라 합 류식 하수도 건설비에 대해 오수 대 빗물의 비율 을 $28: 72$, 유지관리비에 대해 오수 대 빗물의 비 율이 69:31로 조사되었다.

하수도 사업에 대한 국가, 지자체, 개인의 비 용분담체계 현황은 국고보조금, 지방비, 하수도 요금으로 구분할 수 있다(Table 2 참조). 국가는 하수도법 제 63 조에 의거 공공하수도의 설치 및 개축 또는 재해복구에 관한 공사비용의 전부 또 는 일부를 예산의 범위 안에서 지자체에 보조할
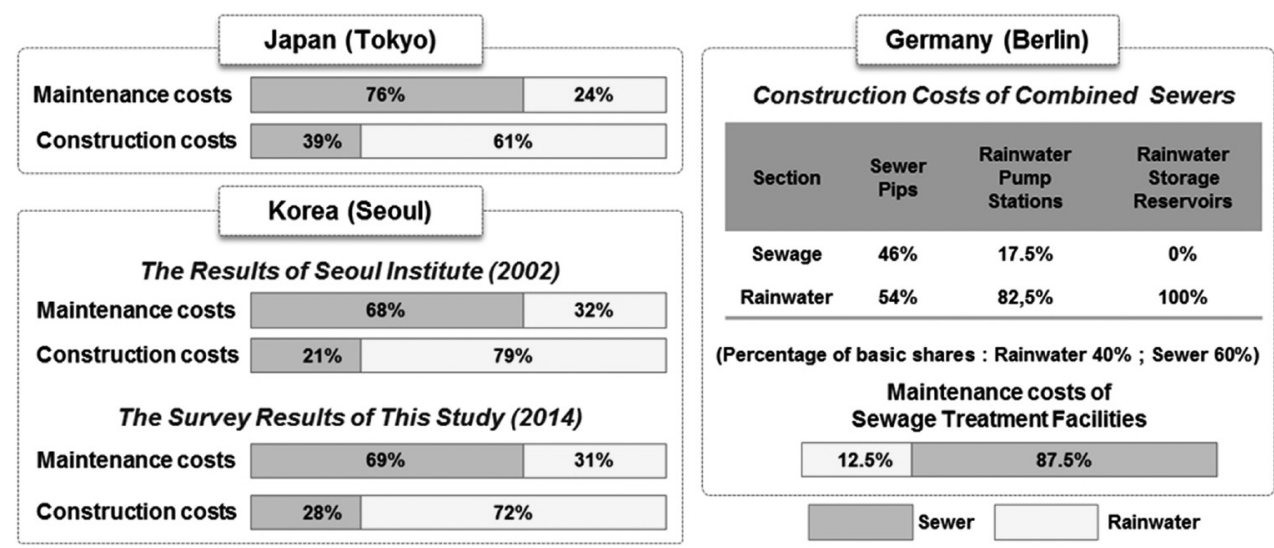

Fig. 3. Comparison of cost sharing for domestic and foreign service of rainwater and sewage collection and treatment.

Table 2. Cost sharing system for sewerage service of central government, local government, and individuals

\begin{tabular}{|c|c|c|c|}
\hline Cost sharing & Contents & Legal Basis & Remarks \\
\hline \multirow{2}{*}{$\begin{array}{l}\text { Central } \\
\text { Government }\end{array}$} & $\begin{array}{l}\text { The installation and reconstruction } \\
\text { costs of public sewer }\end{array}$ & Article 63 of the Sewerage Act & - \\
\hline & $\begin{array}{l}\text { Expansion of sewage treatment } \\
\text { plants, Reuse of treated wastewater, } \\
\text { Sewer Improvement Project }\end{array}$ & $\begin{array}{c}\text { The Enforcement Ordinance for } \\
\text { Grants Management }\end{array}$ & $\begin{array}{l}\text { Seoul Metropolitan } \\
\text { Government Excluded }\end{array}$ \\
\hline \multirow[b]{2}{*}{$\begin{array}{l}\text { Local } \\
\text { Government }\end{array}$} & $\begin{array}{l}\text { With out special regulations, local } \\
\text { governments expenditure }\end{array}$ & Article 57 of the Sewerage Act & - \\
\hline & $\begin{array}{c}\text { Public purpose, the difference } \\
\text { between the cost of generation and } \\
\text { supply and debt. Installation and } \\
\text { maintenance of rainwater treatment } \\
\text { facilities }\end{array}$ & $\begin{array}{l}\text { Article } 5 \text { of the Enforcement Ordi- } \\
\text { nance for Local Public Enterprise Act }\end{array}$ & $\begin{array}{l}\text { Indefinite range for rainwater } \\
\text { treatment facilities }\end{array}$ \\
\hline Individuals & Public sewer user & Article 65 of the Sewerage Act & $\begin{array}{c}\text { Sewer fee : Levy Rainwater fee : } \\
\text { Non-levy }\end{array}$ \\
\hline
\end{tabular}


수 있도록 하고 있다. 한편, '보조금관리에 관한 법률 시행령'에 의거해 하수처리장 확충사업, 하 수처리수 재이용사업, 하수관로 정비사업에 국 고 보조비율을 정해 두었으나, 특별시는 배제되 어 있다. 하수도법 제 57 조에 의해, "공공하수도 에 관한 비용은 이 법 또는 다른 법률에 특별한 규정이 있는 경우를 제외하고는 당해 공공하수 도관리청이 속하는 지방자치단체의 부담으로 한 다"라고 하여 지방자치단체의 비용부담에 대해 명시하고 있다. 또한 앞서 언급한 바와 같이, 지 방공기업법 시행령 제 5 조에 따르면, 지방자치단 체의 일반회계나 다른 특별회계가 부담금 기타 의 방법에 의하여 부담하여야 할 지방직영기업 의 경비에 대해 명시하고 있다. 특히 하수도사업 에 대해 빗물처리시설의 설치 및 유지에 소요되 는 경비는 일반회계 등이 부담할 경비로 명시하 고 있으나, 빗물처리시설에 대한 명확한 범위의 해석이 필요한 상황이다.

아울러 본 연구에서는 하수도사업의 국고보 조비율 조정이 필요한지에 관한 전문가 설문조 사를 실시하였다. 설문조사 결과(Table 3 참조), 하수처리장 확충사업에 대한 법적인 국고보조비 율이 서울특별시에는 0 인데, 전문가들은 평균 $6 \%$ 의 국고보조가 필요하다고 의견을 제시하였 다. 또한, 하수관로 정비사업에 대한 특별시의 국고보조비율은 $10 \%$, 하수처리수 재이용사업에
대해서도 $9 \%$ 가 특별시에 지원이 필요한 것으로 조사되었다. 서울특별시 하수도사업에 대한 법 적인 국고보조비율이 전무한 것에 비해, 긍정적 인 전문가들의 반응이 특기할 만하다.

하수도사업의 공공부담 범위 확대를 위해서 하수도에 대한 공공 비용부담 원칙의 심도 있 는 연구가 선행되어야 한다. 국내에서는 하수도 에 대한 경시 풍조와 함께 하수도사업의 비용부 담원칙에 대한 관심이 전무했던 상황이다. 재정 및 상하수도 전문가 등 각계 전문가들의 학제간 연구를 통해 하수도사업의 공공부담 원칙(Fig. 4 참조)에 대한 심층적 연구 검토가 필요하다.

지방공기업법, 하수도법, 보조금지원에 관한 법률 등의 법령 개정안이 마련되어 확고한 하수 도사업의 비용부담원칙이 법적으로 적용되도록 함이 필요하다.

\section{3 빗물관리시설 설치자 하수도요금 감면방안}

이 개선방안의 주 목적은 빗물의 공공하수관 로 유입저감을 통한 건강한 물순환 도시조성과 하수도요금 감면을 통한 빗물관리시설 설치확대 분위기 조성 및 공감대 확산에 있다(Fig. 5)

도시물순환 도시 조성을 위하여 빗물관리시 설 설치자에 대한 하수도요금 감면규정이 있거 나 시행예정 또는 입법예고 중에 있다. Seoul

Table 3. Results of questionnaire on suitable subsidiary rate for sewerage business

\begin{tabular}{|c|c|c|c|c|c|c|}
\hline \multirow{2}{*}{ Section } & \multicolumn{2}{|c|}{ Expansion of Sewage Treatment Plant } & \multicolumn{2}{|c|}{ Sewer Rehabilitation Project } & \multicolumn{2}{|c|}{ Reuse of Treated Wastewater } \\
\hline & Existing law & This study & Existing law & This study & Existing law & This study \\
\hline $\begin{array}{l}\text { Metropolitan } \\
\text { Government }\end{array}$ & $0 \%$ & $6 \%$ & $0 \%$ & $10 \%$ & $0 \%$ & $9 \%$ \\
\hline Metropolitan City & $\begin{array}{c}10 \% \\
(\mathrm{TP} 50)\end{array}$ & $\begin{array}{c}15 \% \\
(\operatorname{TP~} 50 \%)\end{array}$ & $\begin{array}{c}30 \% \\
\text { (Renewal 10\%) }\end{array}$ & $\begin{array}{c}30 \% \\
\text { (Renewal 10\%) }\end{array}$ & $30 \%$ & $29 \%$ \\
\hline Provincial Capital & $0 \%$ & $16 \%$ & $\begin{array}{c}50 \% \\
\text { (Renewal 20\%) }\end{array}$ & $\begin{array}{c}51 \% \\
\text { (Renewal 23\%) }\end{array}$ & $50 \%$ & $50 \%$ \\
\hline Cities and Counties & $\begin{array}{c}50 \% \\
(\leq \text { Myeon 70\%) }\end{array}$ & $\begin{array}{c}52 \% \\
(\leq \text { Myeon } 71 \%)\end{array}$ & $\begin{array}{c}70 \% \\
\text { (Renewal 30\%) }\end{array}$ & $\begin{array}{c}68 \% \\
\text { (Renewal 34\%) }\end{array}$ & $70 \%$ & $70 \%$ \\
\hline $\begin{array}{l}\text { Provision area of the } \\
\text { US Forces in Korea, } \\
\text { Radioactive Waste } \\
\text { Disposal Facility }\end{array}$ & $80 \%$ & $71 \%$ & 0 & $9 \%$ & $0 \%$ & $9 \%$ \\
\hline
\end{tabular}

TP : Total Phosphorous 


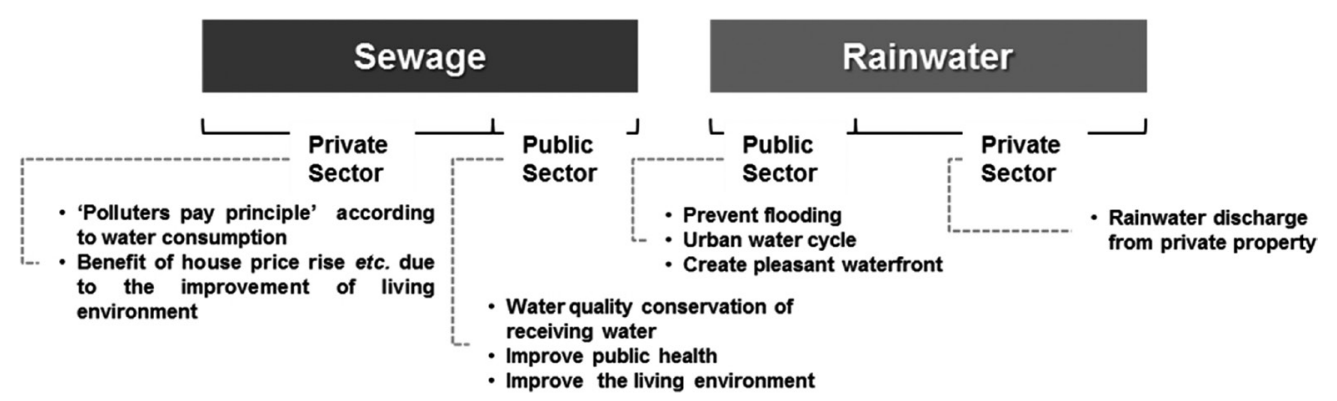

Fig. 4. Principle of sharing costs for sewerage business in public and private sectors.

\begin{tabular}{|c|c|c|}
\hline $\begin{array}{c}\text { Rainwater } \\
\text { Management } \\
\text { Facilities }\end{array}$ & Installers & \\
& Non-Installers & Sewerage fee \\
\hline
\end{tabular}

Fig. 5. Reduction or exemption of sewerage fee for inhabitants of rainwater management facilities.

Metropolitan Government(2013)는 2013년 에 건강한 물순환도시 조성 종합계획을 수립하 고 그 일환으로 빗물관리시설 설치자에 대한 하 수도요금 감면을 추진 중에 있다. 빗물관리시설 설치자에 대한 인센티브로 하수도요금 이외에 각종 감면혜택이 주어지고 있다. 현재 빗물관리 시설 설치자에 대해 하수도요금을 감면해 주고 있는 지자체는 없는 듯하다.

제도 도입을 위해서는 하수도요금은 오수발 생량을 기준으로 산정하므로 빗물저류 또는 침 투량과 감면액(율)과의 상관관계에 대한 별도의 연구가 필요하다. 단기적으로는 감면액 및 감면 규모에 따른 추가 세입 확보방안 마련이 필요할 수 있다. 하지만, 장기적으로는 빗물의 유출 저 감으로 인한 공공하수도의 세출감소로 추가 세 입확보가 불필요할 것으로 예상된다. 빗물관리 시설 설치자에 대한 하수도요금 감면을 강우시 (6월 9월)에만 시행할 것인지, 연중 매월 시 행할 것인지에 대한 정책적 합의가 필요하다. 또 한, 빗물관리시설 설치자에 대한 하수도요금 감 면시, 빗물관리시설 설치에 대한 설치비 보조금 지급의 인센티브 제공 등 다른 정책과 중복으 로 감면혜택을 받을 수 있으므로, 빗물관리시설 의 설치비 보조금 지급액과 이에 따른 하수도요
금 감면액의 상관성을 검토하여야 한다. 빗물관 리시설의 설치자와 보유자가 일치하는 경우에는 설치비 보조금 및 하수도 사용료의 감면으로 설 치 인센티브와 요금감면 혜택이 이중으로 주어 질 수 있으므로 이에 대한 면밀한 검토가 필요 하다(서울시(2014) 보고서에 부지면적, 빗물관 리시설용량, 하수도사용량을 반영한 하수도요금 감면기준표를 예시함). 하지만, 빗물관리시설의 설치비 보조금은 초기의 시설투자자 및 소유주 에게 혜택이 주어지는 반면, 하수도요금 감면은 소유주가 변경된 후에도 빗물관리시설의 보유자 에게 장기적, 지속적으로 이루어지는 감면혜택 이므로 차별성이 있다. 빗물관리시설의 설치보 다는 운영을 통해 실제적인 빗물유출저감과 공 공하수도의 빗물유출 부담을 줄일 수 있으므로, 빗물관리시설의 적정이용 여부에 대한 조사 권 한을 하수도 사용조례에 규정하는 것이 바람직 할 것으로 판단된다.

\section{4 빗물유출부담금제 도입방안}

빗물유출부담금제 도입은 빗물의 공공하수관 로 유입저감을 통한 건강한 물순환 도시조성과 하수도사업 재원확충에 기여하고 개발행위자를 대상으로 부과함으로써 소비자부담을 줄이려는 것이다. 국내 거의 모든 지자체들은 오수량을 기 준으로 하수관로의 용량이 부족한 경우 비용을 부담하도록 규정되어 있다. 서울시의 경우는 공 공하수도의 신설 · 증설 등을 수반하는 개발행위 (타행위)시 오수량을 기준으로 차집관거와 공공 


\begin{tabular}{|c|c|c|c|c|}
\hline \multicolumn{2}{|c|}{ Section } & $\begin{array}{c}\text { Intercepting Sewer } \\
\text { (Sewage) }\end{array}$ & $\begin{array}{c}\text { Public Sewage Treatment } \\
\text { Facilities(Sewage) }\end{array}$ & $\begin{array}{c}\text { Sewer Pipes } \\
\text { (Rainwater) }\end{array}$ \\
\hline \multicolumn{2}{|c|}{ Current } & \multicolumn{2}{|c|}{ Sewerage fee } & Remption \\
\cline { 1 - 1 } $\begin{array}{c}\text { Expansion } \\
\text { (Rainwater Management Facilities) }\end{array}$ & Installers & Non-Installers & & \\
\cline { 4 - 5 } & &
\end{tabular}

Fig. 6. Imposition of charge for discharging rainwater to sewers due to new development.

하수처리시설에만 비용을 부과하고 있으며, 하 수관로에 대해서는 부과하고 있지 않다. 그러나 최근 인천시에서는 우수량을 기준으로 하수관로 의 신설 - 증설 등을 위한 비용을 부담제도를 신 설하여 시행하고 있다. 본 제도는 타행위에 의한 부담금제도로, 주로 개발사업자에게 1 회에 한해 부과하는 비용으로 정기적으로 사용료가 징수되 는 하수도요금과는 차이가 있다. 개발행위로 인 한 증가되는 빗물 배제 및 처리, 저감을 유도 하기 위해 빗물관리시설 설치자에게는 하수관로 신설 및 증설 비용을 감면하고, 미설치자에게는 비용을 부과하는 것을 Fig. 6과 같이 개선방안을 제안하고자 한다. 단, 이 방안은 빗물의 유출량 저감을 유도할 수는 있으나, 빗물의 오염부하 저 감에 대한 효과는 매우 제한적이다.

이 방안으로 개발사업자가 개발사업을 계획 하면서 개발지역에서의 빗물유출량을 줄이려는 노력을 유도할 수 있으며, 개발지역에 빗물이용 시설이나 빗물저류조 등의 우수유출저감시설을 설치하도록 유도하여 원인자부담금 산정에서 제 외되도록 하는 감면제도를 함께 시행하는 것이 다. 제도도입을 위하여 인천시에서 시행하고 있 는 사례를 조사하여 예상되는 문제점과 기대효 과 등 벤치마킹이 필요하다. 원인자부담금은 오 수량을 기준으로 부담시킬 수 있도록 규정되어 있고 “오수”의 범위에 빗물은 포함하지 않고 있 어 빗물에 대한 원인자부담금을 부과할 경우 하 수도법 개정이 수반되어야 하는지 확인이 필요 하다. 하수도사업 재원확충에 기여하고 개발행 위자를 대상으로 부과하여 소비자의 부담이 없 으므로 도입이 용이하며, 오히려 늘어난 빗물 처 리비용을 하수도사용료만으로 충당하는 불합리
성과 비형평성 문제를 해결할 수 있다.

\section{4. 결 론}

본 연구에서 하수도서비스의 비용부담원칙을 검토한 후, 국내 하수도 요금 체계 개선을 위해 제안한 4 가지 개선 방안에 대해서 다음과 같이 제안하였다.

독일식 원인자부담 원칙에 의한 빗물요금제 도입방안이 제시되었다. 하지만, 원인자부담 원 칙에 입각한 빗물요금제를 도입하기 위해서는 시민의 동의, 법적근거, 관련 인프라, 오수와 우 수의 비율 및 공공부분의 비용 분담 부분 등과 같 은 선행 해결과제가 많으므로 장기적으로 추진 되어야 한다. 따라서 시민의 여론 수렴, 정부 국회 · 민간단체 · 전문가 등과 공조체제를 유지 하여 빗물요금제 도입을 위한 공감대를 형성한 후 타당성검토 및 법적인 근거와 함께 관련인프 라 구축이 필요하다.

하수에는 오수 외에 빗물을 포함하고 있으므 로 공공의 비용부담을 확대해야 한다는 논리를 따르는 방안은 지자체의 노력만으로는 한계가 있으므로 정부, 국회, 전문가 등과 공조체제를 유지하여 추진하는 것이 바람직할 것으로 판단 된다. 하수도에 대한 공공 비용부담 원칙의 심도 있는 연구 선행, 각계각층의 공감대 형성, 법제 도적인 측면의 개선방안, 대국민 홍보 등과 같 은 선행되어야 할 과제가 많다. 단기적으로 시 급한 지역에 국고보조금 지원관련 규정 개정 및 개별사업에 대한 국고보조금 확보 방안 추진이 필요하다.

빗물관리시설 설치자에 대한 하수도요금 감 면방안은 하수도시설의 부하경감 및 건강한 물 
순환 도시 조성을 위해 필요하다. 제도도입을 위 해서는 하수도요금은 오수발생량을 기준으로 산 정하므로 빗물저류 또는 침투량과 감면액(율)과 의 상관관계에 대한 별도의 연구가 필요하다. 또 한, 빗물관리시설 설치자에 대한 하수도요금 감 면시, 다른 정책과 중복으로 감면혜택을 받을 수 있으므로 사전에 충분한 검토가 필요하다.

인천시에서 이미 도입한 빗물유출부담금제 도 입방안은 개발사업자에게 빗물유출량을 줄이려 는 노력을 유도하여 하수도시설의 부하경감 및 건강한 물순환 도시의 조성을 위해 서울시 뿐 아 니라 다른 지자체에서도 도입을 검토하는 것이 필요할 것이다.

제도도입의 난이도를 고려하여, 단기적으로 빗물유출부담제와 빗물관리시설 설치자에 대한 하수도요금 감면을 실시하고, 중기적으로 하수 도에 대한 공공부담 확대정책을 펴 나가되, 장 기적으로 또한 궁극적으로 원인자부담원칙에 충 실히 따르는 하수도요금 부과체계를 갖추어 가 야 할 것이다.

\section{사 사}

본 연구는 2013년 2014년에 서울시 물관리 국의 지원에 의해 수행한 '하수도사업 재정운영 효율화 방안 연구’의 결과물의 일부를 발췌한 것 으로 이에 감사를 드립니다.

\section{References}

Bureau of Sewerage Tokyo Metropolitan Government (2013) Business Overview for Tokyo Sewer Project.

Campbell, C. W. (2012) The Western Kentucky University Stormwater Utility Survey 2012, www.wku.edu/swusurvey, Bowling Green, Kentucky.

DWA (2007) Wirtschaftsdaten der Abwasserbeseitigung.

Hennig, B. (2000) Getrennte Entgelte fuer Schmutzwasser und Niederschlags wasser in Berlin. Info Forum Regenmanagement -
Regenwasser bewirtschaftungs systeme in Berlin und Brandenburg. GEOAgentur.

Incheon Metropolitan City (2013) An Introduction Plan of Rainwater Liability Amount for Amicable Sewerage Treatment.

Incheon Metropolitan City (2014) Ordinance for Sewerage Use.

Kwon, K.H. and Hur, O. K. (2010) A measure for improvement of legal fairness by sewage charge : Introduction of German separate sewage charge system as case study, Korea Research Institute for Local Administration, 24 (4), 293-318.

Ministry of Environment (2012) Study on the Introduction of Rainwater Pollution Fee for the Management of Non-point Source Pollution.

Ministry of Environment (2014) Sewerage Act.

Ministry of Internal Affairs and Communications (2006) Research Group Report on the Future Sewer Financial Plan of Japan.

Ministry of Internal Affairs and Communications (2013) Local Public Enterprise Act and Enforcement Ordinance of Japan.

Ministry of Security and Public Administration (2014) Local Public Enterprise Act and Enforcement Ordinance.

Ministry of Strategy And Finance (2014) Act and Enforcement Ordinance for Grants Management.

Pecher, R. (1997) Aufteilung von Bau-und Betriebskosten auf Schmutz-und Regenwasser. awt. abwassertechnik. Heft (4), 17- 20.

Seoul Metropolitan Government (2002) An Investigation and Research for Public Enterprise Special Account Adoption in Sewerage Project.

Seoul Metropolitan Government (2012) Policy Debates for Adopting Rainwater Fee.

Seoul Metropolitan Government (2013) Comprehensive Plan for City of Healthy Water Cycle.

Seoul Metropolitan Government (2014) A Study of Financial Operations Efficiency for Sewerage Project.

Seoul Metropolitan Government (2014) Ordinance for Sewerage Use. 